\title{
Traditional soapstone storage, serving, and cookware used in the Southern states of India and its culinary importance
}

\author{
Aruna Jyothi Kora ${ }^{1,2}$ [D
}

\begin{abstract}
Background: The hand-carved, traditional, versatile kitchen utensils made up of soft soapstone are used and treasured since the rise of civilization in India, especially in the southern states: Andhra Pradesh, Telangana, Tamil Nadu, Karnataka, and Kerala. They are called as rathi chippa and kal chatti and employed for cooking, serving, and storing food for many generations.

Results: The soft soapstone is chemically characterized as steatite and mainly composed of talc. The cookware of varying colors, shapes, and sizes are hand made by the artisans from Tamil Nadu state and offered for sale in the shops located in temple premises and during annual temple festivals. The delicate cookware requires proper conditioning and care while cooking, handling, and cleaning. Such inert cookware has positive quality properties such as low dielectric, high temperature resistance, high density and high mechanical strength. These characteristics have been reflected on the cookware application in cooking foods that require longer cooking time over a gentle fire, and sour, acidic, tamarind containing dishes. They are extensively used for making liquid, gravy-based curries and semi-solid foods; storing and preserving milk, curd, buttermilk, rock salt, tamarind, extracts, pickles, etc.

Conclusions: Notably, the food cooked in soapstone cookware retains the natural, authentic, original aroma and taste. As an insulator, it acts as a casserole by keeping the food hot for longer durations. Being extremely dense and non-porous, it is impervious to bacterial penetration and prevents the bacterial growth on the surface as well as extends the shelf life of cooked foods. Fascinated by traditional importance, distinct taste and health benefits, and tired of factory-made things, the current generations are shifting toward these handmade, exclusive soapstone products.
\end{abstract}

Keywords: Cookware, Soapstone, Shelf life, Southern states of India, Traditional, Taste, Steatite, Non-porous

\section{Introduction}

Before the discovery of iron and other metals (in the Stone Age), the primitive human beings used to carve the stone in the form of vessels and employed them for cooking (Eenadu 2018). In the developed society of current age, the health-conscious people are shifting toward stone vessels by keeping aside the aluminum,

Correspondence: koramaganti@gmail.com

${ }^{1}$ National Centre for Compositional Characterisation of Materials (NCCCM), Bhabha Atomic Research Centre (BARC), ECIL PO, Hyderabad 500062, India ${ }^{2}$ Homi Bhabha National Institute (HBNI), Anushakti Nagar, Mumbai 400 094, India stainless steel (SS), non-stick, and plastic cookware. The aluminum $(\mathrm{Al})$ vessels are available at a cheaper price and SS cookware is easy to clean. In the case of nonstick ware, dishes can be made without food sticking into the vessel by utilizing no or minimum oil. The plasticwares are widely used for storing and heating the food in a microwave oven. However, the utility of the modern cookware is also combined with various detrimental effects on our health. The release for $\mathrm{Ni}$ and $\mathrm{Cr}, \mathrm{Al}$ and Teflon, and Si into the food from SS, aluminum, and non-stick cookware, respectively may lead to cancer, Alzheimer's, asthma, kidney disorders, etc. (Eenadu

\section{Springer Open}

(c) The Author(s). 2020 Open Access This article is licensed under a Creative Commons Attribution 4.0 International License, which permits use, sharing, adaptation, distribution and reproduction in any medium or format, as long as you give appropriate credit to the original author(s) and the source, provide a link to the Creative Commons licence, and indicate if changes were made. The images or other third party material in this article are included in the article's Creative Commons licence, unless indicated otherwise in a credit line to the material. If material is not included in the article's Creative Commons licence and your intended use is not permitted by statutory regulation or exceeds the permitted use, you will need to obtain permission directly from the copyright holder. To view a copy of this licence, visit http://creativecommons.org/licenses/by/4.0/. 
2018). While, the plastic cookware release toxic substances including bisphenol A, melamine, vinyl chloride, and phthalates into the food during usage. Most of them act as carcinogens, endocrine disrupting chemicals, and xenoestrogens, and cause kidney damage (Kora 2019). The stone vessels are mainly made up of soapstone, derived the name from its soapy and smooth surface texture. Their utilization in daily household cooking is abundant nearly 20 -30 years ago (Eenadu 2018; Quintaes et al. 2002). Currently, people are tired of factory-made things and centric toward organic and handmade, exclusive products that have both traditional importance as well as health benefits. Now, it is the time to rejuvenate the cooking traditions of ancestors for relishing the distinct taste and aroma of food cooked and stored in soapstone cookware. We have to take out the forgotten soapstone cookware stacked in our attics and start utilizing them (Adlakha 2017; Zishta.com 2018a).

Soapstone storage and cookware are known as rathi chippa, kal chatti, and makal chatti in Telugu and Tamil languages, respectively. These hand-carved, traditional, versatile kitchen utensils are employed for cooking, serving, and storing food in the Southern states of India: Andhra Pradesh, Telangana, Tamil Nadu, Karnataka, and Kerala. They are made, used, and treasured since the rise of civilization. The talc rich, non-porous, soft rock is highly valued as it is easily carvable into massive forms, cooking pots, vessels, small utensils, and food containers (Baron et al. 2016; Damick and Woodworth 2015; Yenugu 2012; Jones et al. 2007). The local artisans in Salem and Cuddalore, Tamil Nadu and Puducherry have the ability to break the quarried larger rocks and sculpture into cookware with various shapes, volumes, weights, heights, and diameters (sizes) with or without lids. They include storage containers, bowl-shaped pan/mookudu/kadai, serving bowls, pots, storage jars, penam/kallu/tawa/pan, paniyaram chatti, and mortar and pestle (Fig. 1). The color of these vessels varies from lighter to darker shades of gray, green, brown, black, and white. In spite of their weight, they are safely microwavable and easy to wash (Zishta.com 2018a). The artisans work manually for hours with a chisel and wooden block from excavating the stone block to filing the vessel and finally finishing into a distinct and delicate masterpiece. A single handmade vessel is the result of focus, skill, and precise craftsmanship for hours. Also, cooking plates and countertops which can be used in grills and ovens are also made with soapstone. They are also used for making soppu saman, a miniature kitchen utensil toy set for girls (Fig. 2) (CulturalIndia.net 2016; Eenadu 2018; Kandaswamy 2016; Zishta.com 2018a; Zishta.com 2018b; Zishta.com 2018c).

The soapstone is a perfect medium of carving material for soft stone artifacts, sculptures, decorative architecture, single wick lamps, fireplaces, and stoves, as it is softer than marble and granite (Kandaswamy 2016; Storemyr 2004). The practice of making and using mineral-rich soapstone cookware and vessels is prevalent in India even much before the $3^{\text {rd }}$ Century BC (Eenadu 2018). One such example is the Hoysaleswara temple located at Halebidu of Karnataka state. The temple is carved from the soapstone with sculptures, intricate shapes, and reliefs, iconography, inscriptions showcasing the life and culture of South India in the $12^{\text {th }}$ century (Nair Srijith 2014). The utilization of soapstone cookware and vessels, artifacts, decorative objects, sculptures, statues, and ornaments such as stone beads is also found in Indus Valley civilization (Damick and Woodworth 2015) and various countries such as South America, North America, Canada (Baron et al. 2016), Lebanon (Damick and Woodworth 2015), Israel, Turkey (BarYosef Mayer et al. 2004), Egypt, (Eliyahu Behar et al. 2016), Nigeria (Ige and Swanson 2008), Europe from Scandinavia to Northern Britain (Jones et al. 2007); Brazil (Quintaes et al. 2002; Rodrigues and Lima

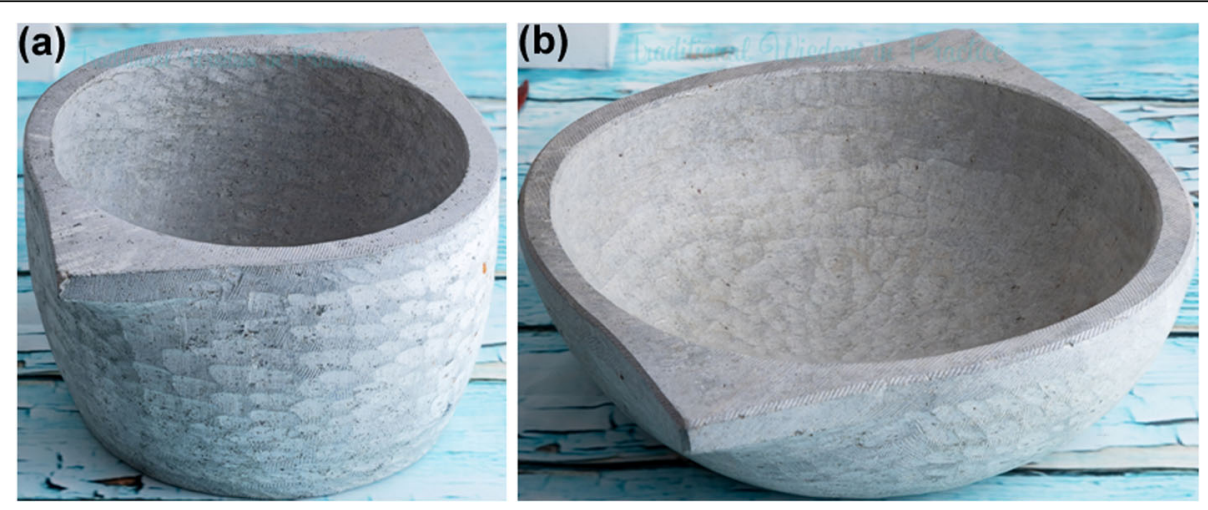

Fig. 1 The soapstone made a storage container and $\mathbf{b}$ bowl shaped pan/mookudu/kadai 


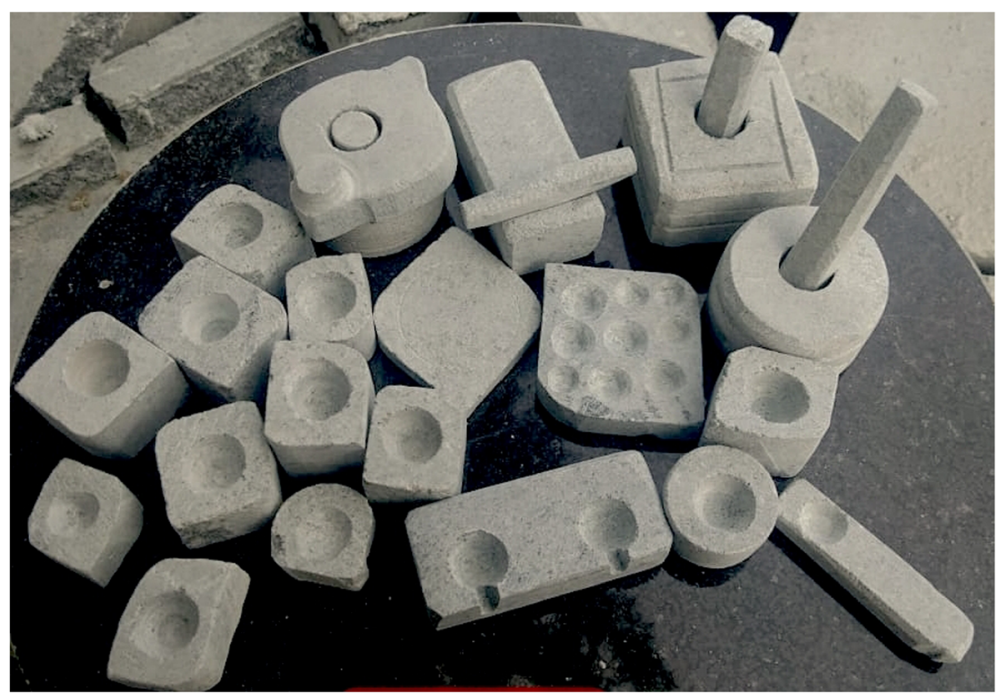

Fig. 2 The soapstone made soppu saman, a miniature kitchen utensil toy set for girls

2012), Central Italy (Santi et al. 2009), and Norway (Storemyr 2004).

\section{Composition and properties of soapstone}

According to Baron et al. 2016, Damick and Woodworth 2015, Jones et al. 2007, the soapstone is geochemically characterized as steatite. The soft stone steatite is an easily carvable, dense, durable, heterogeneous rock. It is formed with processes known as metamorphosis and metasomatism by combining talc deposits with other minerals. It is primarily composed of varying quantities of mineral, talc (30-90\%), and varying quantities of accessory mineral silicates such as chlorite and magnesium carbonates (dolomite, magnesite). The talc is a naturally occurring mineral and composed of hydrous magnesium silicate $\left(\mathrm{Mg}_{3} \mathrm{Si}_{4} \mathrm{O}_{10}(\mathrm{OH})_{2}\right)$. The talc is formed with diffusion of $\mathrm{Si}$ into igneous rocks during hydrothermal and metasomal chemical reactions induced by temperature and pressure. The inclusion of certain trace elements and crystallographic structure impart different color gradations to the steatite. For example, $\mathrm{Fe}$ and $\mathrm{Ni}, \mathrm{Cr}$ and $\mathrm{Cu}$ give green color, dark green color with violet spots, and bluish-green color, respectively (Baron et al. 2016). The geochemical characterization of rare earth elements (REEs) and trace transition metals such as $\mathrm{Co}, \mathrm{Cr}, \mathrm{Sc}, \mathrm{V}, \mathrm{Zn}, \mathrm{Mn}$, and $\mathrm{Fe}$ provides geochemical fingerprint for the raw materials, thus, leading to identification of archaeological artifacts. Especially, trace transition elements such as $\mathrm{B}, \mathrm{Ni}, \mathrm{Sc}$, As, $\mathrm{Cu}, \mathrm{Sb}, \mathrm{Co}, \mathrm{Zn}$, and $\mathrm{Cr}$ are capable of differentiating the steatites (Baron et al. 2016; Jones et al. 2007). Most of the architectural soapstone is mined from Chile, Brazil, India, and Finland, and exported to the USA. The Indian soapstones are classified as palewa and gorara varieties. The palewa soapstone variety is gray in color and becomes darker upon hand polishing. While, the gorara variety mined from Rajasthan and Central India is mottled and available in a range of colors such as rich yellow, brown, pink, green, deep purple, and black (Tara 2014).

An array of characterization techniques such as inductively coupled plasma optical emission spectroscopy (ICP-OES), inductively coupled plasma mass spectrometry (ICP-MS), laser ablation inductively coupled plasma mass spectrometry (LA-ICP-MS), laser ablation time of flight inductively coupled plasma mass spectrometry (LA-TOF-ICP-MS), neutron activation analysis (INAA), particle induced X-ray emission (PIXE), particle induced gamma ray emission (PIGE), atomic absorption spectrophotometry (AAS), Mössbauer spectroscopy, energy dispersive energy-dispersive X-ray fluorescence (ED-XRF), $\mathrm{X}$-ray diffraction (XRD), thermogravimetric analysis (TGA), visible near infrared reflectance spectrometry, optical microscopy, scanning electron microscopy (SEM), Brunauer-Emmett-Teller (BET) surface area, Fourier transform infra-red spectroscopy (FTIR), Raman spectroscopy, petrography, color and texture were extensively used for compositional analysis of steatite (BarYosef Mayer et al. 2004; Baron et al. 2016; Damick and Woodworth 2015; Eliyahu Behar et al. 2016; Ige and Swanson 2008; Jones et al. 2007; Olabanji et al. 1991; Olabanji et al. 1990; Reynard et al. 2008; Rodrigues and Lima 2012; Santi et al. 2009; Torres et al. 2015).

The steatite is bestowed with unique properties such as low dielectric, high density, high specific heat capacity, high temperature resistance, high mechanical strength, and high resistance to acids and alkalis (Table 1) (Gökçe et al. 2011; Hand 2020; Reynard et al. 2008; Santi et al. 
Table 1 The physical, chemical, mechanical, and thermal properties of soapstone (Gökçe et al. 2011; Hand 2020; Reynard et al. 2008; Santi et al. 2009)

\begin{tabular}{ll}
\hline Property & Value \\
\hline Class & Metamorphic rock \\
Sub class & Durable, soft rock \\
Color & Black, brown, gray, green, white \\
Geological characterization & Steatite \\
Chemical composition & Talc and minerals \\
Density (g/ $\left.\mathrm{cm}^{3}\right)$ & $2.6-2.9$ \\
Mohr's hardness & 1 \\
Thermal conductivity $(\mathrm{W} / \mathrm{mK})$ & $0.8-2.9$ \\
Specific heat capacity $(\mathrm{J} / \mathrm{gK})$ & $0.7-0.9$ \\
Melting point temperature $\left({ }^{\circ} \mathrm{C}\right)$ & $>1600$ \\
Compressive strength $(\mathrm{MPa})$ & $10-40$ \\
Transverse strength $(\mathrm{MPa})$ & 12.6 \\
Modulus of rupture $(\mathrm{MPa})$ & $10-13.2$ \\
Water resistance & + ve \\
Heat resistance & + ve \\
Pressure resistance & + ve \\
Acid and alkali resistance & + ve \\
\hline
\end{tabular}

2009). The color, texture, and amenability to carving are the attractive features of this metamorphic rock.

\section{Availability of soapstone cookware}

Mostly, the soapstone cookware is sold in the shops located in the premises of many temples in the state of Tamil Nadu. For example, the kal chatti are available in the shops around the Ranganatha Swamy temple, Srirangam; Meenakshi Amman temple, Pudhu Mandapam, Madurai; Kamakshi temple, Kancheepuram; Bruhadeeswara temple, Thanjavur; Adi Kumbheswarar temple, Kumbakonam; Shore temple, Mamallapuram; Parthasarathy temple, Triplicane; Kapaleeswarar temple, Mylapore, Chennai; Chinna Kadai Mariamman temple and Kanda Swamy temple, and Parry's Corner, Chennai. They are also found in the shops located in the premises of Jagannath temple, Puri, Odisha. Some of the vessel and utensil shops located in Chennai such as Rathna stores, Sundar stores, Ponni stores, Kamala stores, Saravana stores, and Vijay stores in Namakkal stock the soapstone cookware for sale. Also found in Dakshinachitra Heritage Museum, Muttukadu, Chennai; Zam Bazar, Triplicane, Chennai; gift shops, puja stores, and exhibitions conducted by Crafts Council of India in various cities (Indusladies.com 2016; Srinivasan 2019; Yenugu 2012). They are also sold in the streets of heritage village known as Kalpathy located in the Palakkad district of Kerala state, during the Rathotsavam (chariot festival) of Viswanatha Swamy temple, an annual event in the month of November. It is common to find them in the stalls and local shops during the annual temple festivals of Kilur, Koyilandy, Kuttiyadi, Naduvannur, Perambra, Thalassery, and Thaliparamba of Kerala state and during Orkkatteri cattle fair of Orkkatteri, Kozhikode district, Kerala (Rajesh 2011). The vessel shops of Palakkad also sell the cookware (Wordpress.com 2017). The soapstone cookware and vessels are marketed online by many websites such as Zishta.com and popularizing their utility in the current generation. Especially, the firm Zishta ensures the quality of their products in terms of levels of $\mathrm{Ca}$ and absence of artificial colors by testing them in National Accreditation Board for Testing and Calibration Laboratories (NABL) accredited laboratories and complies with EU standards for restriction of hazardous substances (RoHS) (Zishta.com 2018b). Antique collectors such as Yenugu Krishna Murthy are still preserving the collections of various traditional soapstone cookwares (Yenugu 2012). It is significant to note that the practice of cooking food and offering naivedyam to various gods and goddess in soapstone cookware is still exists in some temples of India (Eenadu 2018).

\section{Seasoning of soapstone cookware}

As the soapstone wares are soft and fragile, it is mandatory to season them before utilizing for cooking purpose, which is time consuming. The seasoning/condition/curing process of soapstone cookware is known as mayakkal in Malayalam language. The seasoning is done for expedition of natural oxidation leading to uniform darkening of the surface; protection of the internal surface, prevention of extensive erosion during cooking; repression of toxic mineral migration $(\mathrm{Al}, \mathrm{Ni}, \mathrm{Cr})$, selective migration of beneficial minerals $(\mathrm{Ca}, \mathrm{Mg}, \mathrm{Fe}$ ) into the food and enhancement in durability of soapstone cookware, thus making the surface much denser (Quintaes et al. 2002). With seasoning and usage, the color of soapstone cookware becomes darker, which is a common observation by the users (Fig. 3). There are various traditional methods of seasoning practiced in households of the Southern states of India. One is soaking the vessels in rice rinsed water known as kazhani/kadugu for 1 day, boil in the same water till bubbling and thorough rinsing with plain water for 3-4 times. The same procedure has to be repeated for 3-4 days. The second method is filling the water containing stone vessel with wild, backyard grown leaf vegetables and boiling, which has to be repeated for 3-4 times. The third way is by coating the exterior and interior of vessel with a mixture of turmeric and gingelly or castor oil and drying aside for 3 days. Further, the washed vessel has to be filled with either kazhani/kadugu or hot ganji/kanji, which has to be repeated for 4 days. The sieved, starchy water obtained after cooking the rice in excessive water is known as 


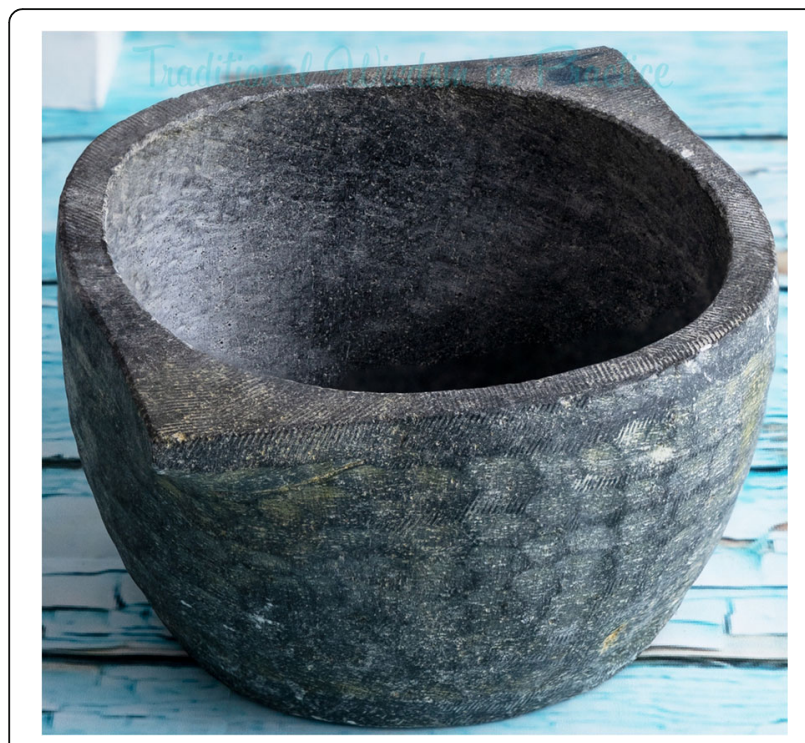

Fig. 3 The seasoned soapstone vessel, kal chatti indicating the darker coloration

ganji/kanji. Then, the water-filled vessel has to be boiled in low flame, a process which has to be repeated for 4 days. Finally, on the 10th day, the conditioned vessel is ready for cooking (Zishta.com 2018b). Another way of conditioning is filling the pot with ganji/kanji and incubating for a day and repeating the same process for 6-7 days. Nowadays, the pre-seasoned stoneware is commercially available from various online stores. With increase in age, the quality of rathi chippa improves leading to an enhancement in the taste of the cooked food (Indusladies.com 2016; Yenugu 2012; Zishta.com 2018d).

It is important to remember that utmost care is needed while handling and cooking in soapstone cookware. The vessels should not be exposed to direct flame, without water or any liquid in it, which leads to immediate cracking of the pot. They should be used under low flame with liquid or water in it. While cleaning, they should not be filled with cold water before reaching the room temperature. They are easy to wash with liquid soap or bar without wire scrubbing as the food does not stick to the walls. In the Southern states of India, it is a traditional custom to pass the age-old soapstone vessels within the families from one generation to the other with utmost care, love, and attachment (Fig. 4) (Gayatri 2019; Yenugu 2012; Zishta.com 2018b).

\section{Utilization of soapstone cookware}

The chemically inert soapstone cookware is mostly used for cooking and making liquid, gravy-based curries, semi-solid soups, and other food items that need to be cooked slowly for a longer duration over a gentle fire. They are employed for making vegetarian, meat (chicken, mutton, beef), and fish-based dishes. The liquid-based foods include rasam, sambar, and the gravy-based curries consist of pappu pulusu, mukkala pulusu, majjiga pulusu, gongura pulusu, dappalam, chepala pulusu, vatha kuzhambu, kara kuzhambu, mor kuzhambu, millagu kuzhambu, avial, kadhi, and others (Kandaswamy 2016; Yenugu 2012). The semi-solid dishes comprise of pappu, kootu, molagatal, keerai masiyal, and kappayum irachiyum. Especially, the sour, acidic, tamarind containing food items such as vatha kuzhambu, kara kuzhambu, pappu pulusu, dappalam, rasam, and sambar are prepared in the inert cookware (Fig. 5). In comparison with brass and bronze vessels, they are preferred, as they do not produce green oxide rusty layer after interacting with tamarind (Gayatri 2019). The soapstone pan is used for making dosa, neer dosa, roti, and paratha (Fig. 6). The paniyaram chatti is a 7-9 pit containing special soapstone carved vessel. It is used exclusively for making south Indian breakfast such as kuzhi paniyaram, appam, unniyappam, and paddu (Fig. 7). They are also used for storing and preserving milk, curd, buttermilk, rock salt, tamarind, extracts, pickles, etc. The pickles stored in kal chatti tastes fresh

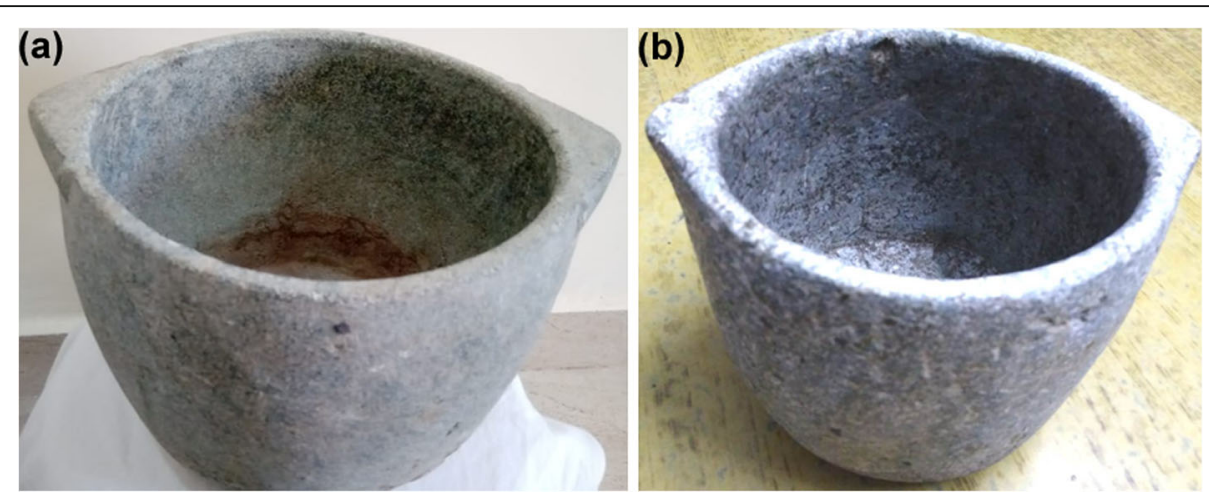

Fig. 4 Century old soapstone vessels/rathi chippa inherited from generations and extensively used for a cooking gongura pulusu and $\mathbf{b}$ storing tamarind 


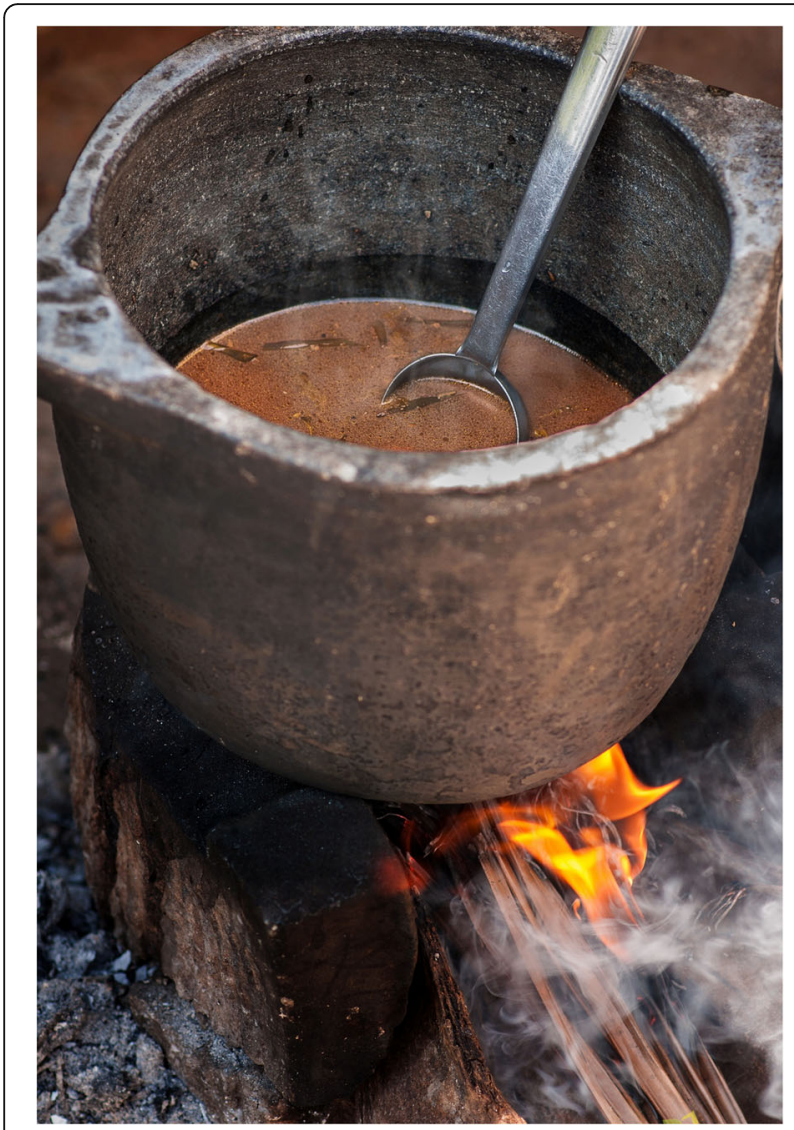

Fig. 5 The liquid based, sour, acidic, tamarind containing food item rasam is being prepared in kal chatti placed on traditional, fire wood burning stove

and much better for years due to the seepage of natural minerals into them, thus enriching the nutrition with supplements (Yenugu 2012; Zishta.com 2018d). They are ideal containers for setting tasty and thick curd within 4-5 h. Furthermore, they are used for storing curd against fermentation, which results in sour taste. In olden days, it is a common practice to preserve the curd fresh in rathi chippa, where refrigerators were no longer invented (Fig. 8). They are also used for storing cooked food items such as kootu, vatha kuzhambu, kuzhambu, thogayal, and рарри. In addition, they are used for storing tamarindbased concentrates such as puli kachal and puli inji, batters, and pazhaya sadham/chaddannam. The mortar and pestle is used for the effective crushing and grinding of spices, condiments and herbs used during cooking (Indusladies.com 2016; Wordpress.com 2017; Yenugu 2012; Zishta.com 2018a; Zishta.com 2018b; Zishta.com 2018d). In traditional houses of Thanjavur, the waterfilled stone crock-pots are employed for decorating with colorful flowers (Mathew 2000).

\section{Advantages of soapstone cookware}

The presence of chemically inert talc in soapstone makes it heat, acid, alkali, chemical, alcohol, etch, dirt, and stain resistant. Thus, the cookware is durable toward common acid (lemon) and alkali (ammonia)-based household dish wash cleaners. Also, the extremely dense and nonporous nature of the soapstone cookware is impervious to bacterial penetration and prevents the bacterial growth as well as extends the shelf life of the cooked foods for a longer duration. As a result, the cooked food stays edible and fresh without refrigeration. The talc, a major component of soapstone is considered as generally regarded as safe (GRAS) by US Food and Drug Administration (FDA). Quintaes et al. 2002 reported that the utilization of soapstone cookware for culinary purpose is safe in terms of $\mathrm{Cd}$ and $\mathrm{Pb}$ toxicity. Also, the mineral enriched, cured soapstone cookware releases minerals such as $\mathrm{Ca}, \mathrm{Mg}$, and Fe during cooking and makes the food not only fresh, delicious but also healthy by contributing to mineral nutrition. It is significant to note that less oil is required during cooking, as the heat is

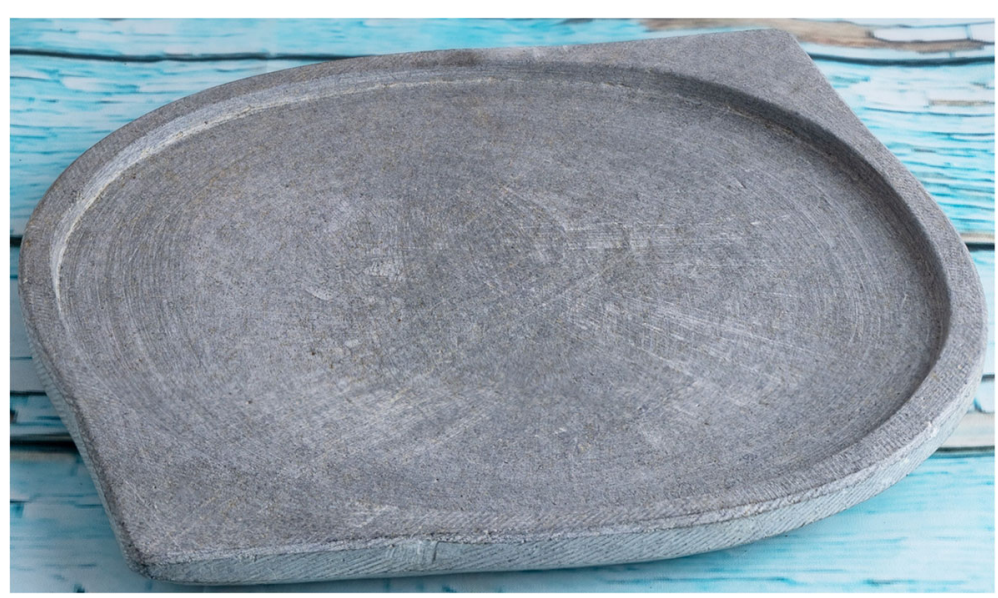

Fig. 6 The soapstone pan used for making dosa, neer dosa, roti, and paratha 

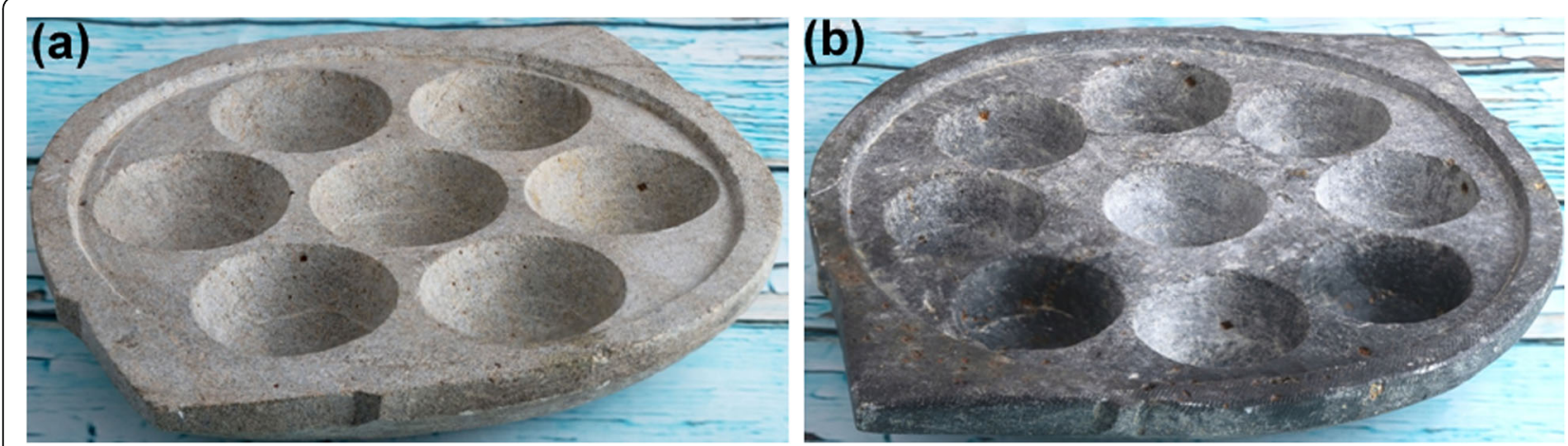

Fig. 7 The soapstone paniyaram chatti with $\mathbf{a} 7$ pits and $\mathbf{b} 9$ pits

absorbed faster and distributed uniformly in all the directions. By cooking in soapstone cookware, energy and fuel can be saved by switching off the heat source few minutes before due to their ability of heat retention. Therefore, the soapstone cookware acts as a slow cooker. Being a good insulator, the heat dissipation to the surroundings is slow. Hence, the food cooked in the soapstone vessel retains the temperature for a long time and remains hot for 4-5 h, in comparison with $\mathrm{Al}$ and SS vessels (Kandaswamy 2016; Rajesh 2011). Additionally, the kal chatti acts as a casserole or serving hot pack. It is also used for keeping the food cold for a larger time, due to its non-porous nature. It is a nostalgic feeling for elder generation people such as grandmothers and grandfathers, when they recollect their childhood memories of mouth-watering foods such as pappu pulusu, mukkala pulusu, and others cooked in rathi chippa (Eenadu 2018). The food cooked in rathi chippa tastes better and retains the natural, original aroma, and taste than the food cooked in SS or Al vessels, as it retains all the nutrients and minerals while cooking (Kandaswamy 2016; Rajesh 2011; Yenugu 2012; Zishta.com 2018c;

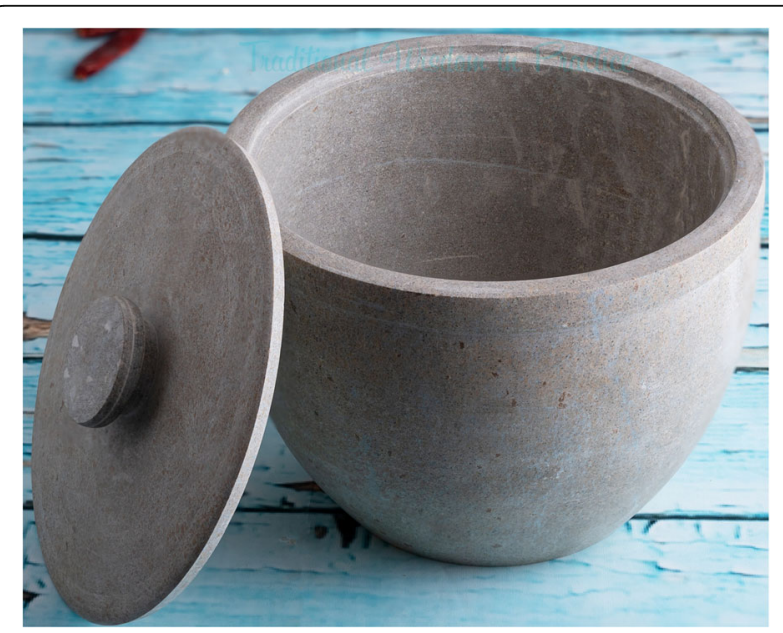

Fig. 8 The rathi chippa used for setting and storing curd
Zishta.com 2018d). Notably, cured soapstone cookware contributes in mineral nutrition by releasing $\mathrm{Ca}, \mathrm{Mg}$, and Fe into the food (Quintaes et al. 2002), in comparison with the mineral toxicity caused by release of $\mathrm{Al}, \mathrm{Cr}$, and Ni by aluminum and SS cookware.

\section{Other applications of soapstone}

The steatite ceramics are extensively utilized in housing, high temperature electrical and electronic components, and applications for their durability, dielectric and thermal insulating properties (Gökçe et al. 2011). They are used for construction of kitchen and laboratory countertops, laboratory floors, sinks, basins, fireplace liners, wood-burning masonry heaters, metal casting molds, and as cladding material for metal wood stoves. They include whisky stones, heating element holders, halogen bulb holders, gas tip burners, thermostat and switchboard casings, interlocking insulating beads, and split bush insulators. Moreover, they are used as a visible and non-permanent marking tool by the welders, fabricators, carpenters, craftsmen, seamstresses, and also found interest in dental applications (Gökçe et al. 2011; Reynard et al. 2008). The steatite cups were used as adsorbent for the removal of trace elements such as $\mathrm{Cu}$ and $\mathrm{Pb}$ from Brazilian spirits (Louvera Silva et al. 2016). The residual soapstone powder recovered from artisan workshops can be utilized in insecticide, paint, pigment, paper, textile, and plastic industries as a filler (Rodrigues and Lima 2012).

The soapstone cookware is prone to dents and scratches by sharp and abrasive objects due to its soft nature; and their surface darkens with age. They are delicate, require seasoning, and little expensive that should be used for cooking only liquid and semi-solid dishes and should not be used for dry heating. Lot of scope is envisaged in soapstone ware in terms of the development of curing methods, cookware design, product range in various sizes and shapes, and marketing. Importantly, the food-grade quality of the raw materials and cured soapstone cookware should be ensured with 
specific reference to toxic metals such as $\mathrm{Cr}, \mathrm{Cd}, \mathrm{Pb}, \mathrm{Al}$, and $\mathrm{Ni}$ to assess their possible leaching, toxicity, and nutritional impact during cooking, serving, and storage of food.

\section{Conclusions}

In the current age of $\mathrm{Al}, \mathrm{SS}$, non-stick and plastic cookware, and their toxic health effects, the interest of people has shifted to traditional soapstone cookware known as rathi chippa or kal chatti. They are widely used for cooking, serving, and storing various dishes and food items in the Southern states of India for many generations. As the cookware is bestowed with various virtues, it is the time to revive and encourage the craftsmanship of the artisans involved in sculpturing of the handmade masterpieces. Various governmental organizations such as Crafts Council of India and online entrepreneurs such as Zishta are popularizing the cookware among the public. It is the high time that we should teach our children about the cultural, religious, medicinal, culinary, nutritional, and socio-economic importance of our age-old traditions, customs, cooking methods, cookware, etc. Probably, that may lead to a renaissance in our active, materialistic, career-centric day to day life.

\begin{abstract}
Abbreviations
AAS: Atomic absorption spectrophotometry; BET: Brunauer-Emmett-Teller; ED-XRF: Energy dispersive energy-dispersive X-ray fluorescence; FTIR: Fourier transform infra-red spectroscopy; $\mathrm{Mg}_{3} \mathrm{Si}_{4} \mathrm{O}_{10}(\mathrm{OH})_{2}$ : Hydrous magnesium silicate; ICP-MS: Inductively coupled plasma mass spectrometry; ICPOES: Inductively coupled plasma optical emission spectroscopy; LA-ICPMS: Laser ablation inductively coupled plasma mass spectrometry; LA-TOFICP-MS: Laser ablation time of flight inductively coupled plasma mass spectrometry; INAA: Neutron activation analysis; NABL: National Accreditation Board for Testing and Calibration Laboratories; PIGE: Particle induced gamma-ray emission; PIXE: Particle induced X-ray emission; REEs: Rare earth elements; RoHS: Restriction of hazardous substances; SEM: Scanning electron microscopy; SS: Stainless steel; TGA: Thermogravimetric analysis; XRD: X-ray diffraction
\end{abstract}

\section{Acknowledgements}

The author would like to thank Dr. Athyala Christian Sahayam, Head, Bulk Analysis Section (BAS), and Dr. Sunil Jai Kumar, Former Head, NCCCM/BARC for their constant encouragement and support throughout the study. The author would like to acknowledge Zishta.com, Bengaluru for providing the soapstone cookware photographs.

\section{Author's contributions}

The author alone involved in data collection, compilation, writing, and interpretation during the manuscript preparation. The author read and approved the final manuscript.

\section{Funding}

No funding source to declare

\section{Availability of data and materials \\ Not applicable}

Ethics approval and consent to participate

Not applicable

\section{Consent for publication}

Not applicable

\section{Competing interests}

The author declares that she has no competing interests.

Received: 21 January 2020 Accepted: 18 May 2020

Published online: 29 May 2020

\section{References}

Adlakha N (2017) Life and style, homes and gardens, back to the stone age, Weekend Edn. The_Hindu. https://www.thehindu.com/life-and-style/homesand-gardens/artisinal-earthenware/article19133289.ece. Accessed 23 July 2018

Baron A, Burke AL, Gratuze B, Chapdelaine C (2016) Characterization and origin of steatite beads made by Northern Iroquoians in the St. Lawrence Valley during the $15^{\text {th }}$ and $16^{\text {th }}$ centuries. J Archaeol Sci Rep 8:323-334. https://doi. org/10.1016/j.jasrep.2016.06.011

Bar-Yosef Mayer DE, Porat N, Gal Z, Shalem D, Smithline H (2004) Steatite beads at Peqi'in: Long distance trade and pyro-technology during the Chalcolithic of the Levant. J Archaeol Sci 31:493-502. https://doi.org/10.1016/j.jas.2003.10. 007

Culturallndia.net (2016) Handmade soapstone utensils. http://www.culturalindia. net/indian-crafts/soap-stone-utensils.html. Accessed 28 Sept 2016

Damick A, Woodworth M (2015) Steatite beads from Tell Fadous-Kfarabida: A case study in early Bronze Age technology in Northern Coastal Lebanon. J Archaeol Sci Rep 3:603-614. https://doi.org/10.1016/j.jasrep.2015.08.028

Eenadu (2018) Kotha 'rathi' yugam, Sunday, Supplement edn. Vasundhara Publications Ltd., Hyderabad

Eliyahu Behar A, Albaz S, Shai I, Maeir AM, Greenfield HJ (2016) Faience beads from early Bronze Age contexts at Tell es-Safi/Gath, Israel. J Archaeol Sci Rep 7:609-613. https://doi.org/10.1016/j.jasrep.2015.11.011

Gayatri (2019) Rachippa pulusu-Andhra telugu recipe vol 2017. Chaaru, rasam, saambaar, perugu pachhallu etc.

Gökçe H, Ağaoğulları D, Öveçoğlu ML, Duman I, Boyraz T (2011) Characterization of microstructural and thermal properties of steatite/cordierite ceramics prepared by using natural raw materials. J Eur Ceram Soc 31:2741-2747. https://doi.org/10.1016/j.jeurceramsoc.2010.12.007

Hand R (2020) Soapstone technical data - calculated. Accessed 21 Jan 2020

Ige OA, Swanson SE (2008) Provenance studies of Esie sculptural soapstone from southwestern Nigeria. J Archaeol Sci 35:1553-1565. https://doi.org/10.1016/j. jas.2007.11.001

Indusladies.com (2016) Where can I buy kalchatti. http://indusladies.com/ community/threads/where-can-i-buy-kalchatti.73662. Accessed 27 Sept 2016

Jones RE, Kilikoglou V, Olive V, Bassiakos Y, Ellam R, Bray ISJ, Sanderson DCW (2007) A new protocol for the chemical characterisation of steatite - two case studies in Europe: The Shetland Islands and Crete. J Archaeol Sci 34: 626-641. https://doi.org/10.1016/j.jas.2006.07.002

Kandaswamy K (2016) Soap stone utensils. Accessed 28 Sept 2016

Kora AJ (2019) Leaves as dining plates, food wraps and food packing material: Importance of renewable resources in Indian culture. Bull Nat Res Centre 43(1):205

Louvera Silva KA, da Costa Fernandes I, Bearzoti E, Milani RF, Morgano MA, Quintaes KD (2016) Evaluation of raw soapstone (steatite) as adsorbent of trace elements present in Brazilian spirits. Food Chem 200:83-90. https://doi. org/10.1016/j.foodchem.2016.01.020

Mathew M (2000) Taste of Thanjavur, Online edn. The Hindu, Chennai

Nair Srijith P (2014) Belur and Halebidu: Epics in stone. https://sreejithpnair. wordpress.com/tag/soapstone. Accessed 17 Apr 2020

Olabanji SO, Cherubini R, Fazinic S, Moschini G, Zafiropoulos D (1991) PIGE analysis of Esie museum soapstone sculptures. Nucl Inst Methods Phys Res A 56-57:726-729. https://doi.org/10.1016/0168-583X(91)95013-4

Olabanji SO, Olarewaju VO, Onabajo O (1990) PIXE analysis of museum soapstone sculptures from Esie, South-West Nigeria. Nucl Inst Methods Phys Res A 47: 415-420. https://doi.org/10.1016/0168-583X(90)90620-A

Quintaes KD, Amaya-Farfan J, Morgano MA, Mantovani DMB (2002) Soapstone (steatite) cookware as a source of minerals. Food Addit Contam 19:134-143. https://doi.org/10.1080/02652030110066206

Rajesh M (2011) Old and beautiful vol 2016. Calicutnet.com

Reynard B, Bass JD, Jackson JM (2008) Rapid identification of steatite-enstatite polymorphs at various temperatures. J Eur Ceram Soc 28:2459-2462. https:// doi.org/10.1016/j.jeurceramsoc.2008.03.009 
Rodrigues MLM, Lima RMF (2012) Cleaner production of soapstone in the Ouro Preto region of Brazil: A case study. J Clean Prod 32:149-156. https://doi.org/ 10.1016/j.jclepro.2012.03.028

Santi P, Renzulli A, Antonelli F, Alberti A (2009) Classification and provenance of soapstones and garnet chlorite schist artifacts from Medieval sites of Tuscany (Central Italy): Insights into the Tyrrhenian and Adriatic trade. J Archaeol Sci 36:2493-2501. https://doi.org/10.1016/j.jas.2009.05.006

Srinivasan P (2019) Keeping legends alive. @The_Hindu. https://www.thehindu. com/entertainment/art/keeping-legends-alive/article19378581.ece. Accessed 25 Apr 2019

Storemyr P (2004) Weathering of soapstone in a historical perspective. Mater Charact 53:191-207. https://doi.org/10.1016/j.matchar.2004.06.015

Tara Projects (2014) Plate palewa stone. http://resources.tenthousandvillages.ca/ cdn/factsheets_v2/English/23/6827023.pdf?t=587103289. Accessed 17 Apr 2020

Torres HSS, Varajão AFDC, Sabioni ACS (2015) Technological properties of ceramic produced from steatite (soapstone) residues-kaolinite clay ceramic composites. Appl Clay Sci 112-113:53-61. https://doi.org/10.1016/j.clay.2015. 04.016

Wordpress.com (2017) Kalchatti trails. https://enthucutletintown.wordpress.com/2 017/03/21/kalchatti-trails. Accessed 25 Apr 2019

Yenugu KM (2012) Antique stone cooking pots vol 2013. Yenugu, Krishna Murthy doi: http://ykantiques.com/2012/05/antique-stone-cooking-pots.html

Zishta.com (2018a) Here is the perfect kalchatti utensil for storage. Zishta.com. Accessed 23 Jul 2018

Zishta.com (2018b) Kalchatti (Soap stone vessel). Zishta.com. Accessed $23 \mathrm{Jul}$ 2018

Zishta.com (2018c) Meeting the makers of stone cookware (Kal chatti). Zishta. com. Accessed 23 Jul 2018

Zishta.com (2018d) Traditional benefits of soapstone vessels. Zishta.com. Accessed 23 Jul 2018

\section{Publisher's Note}

Springer Nature remains neutral with regard to jurisdictional claims in published maps and institutional affiliations.

\section{Submit your manuscript to a SpringerOpen ${ }^{\circ}$ journal and benefit from:}

- Convenient online submission

- Rigorous peer review

- Open access: articles freely available online

- High visibility within the field

- Retaining the copyright to your article

Submit your next manuscript at $\boldsymbol{\nabla}$ springeropen.com 